
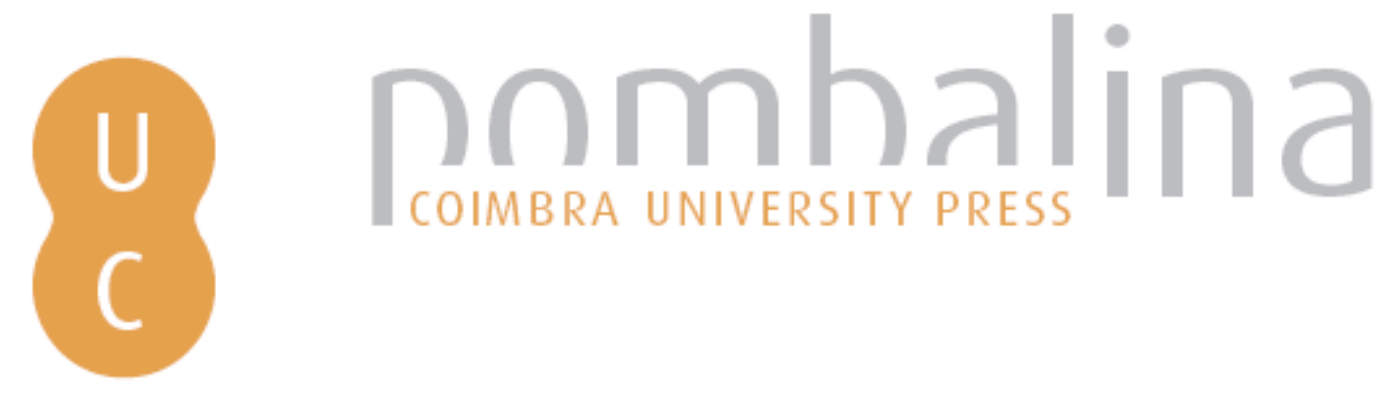

Improvement of forest fire danger rating in Russia

Autor(es): $\quad$ Volokitina, Alexandra V.; Sofronova, Tatiana M.; Korets, Mikhail A.

Publicado por: Imprensa da Universidade de Coimbra

URL

persistente: URI:http://hdl.handle.net/10316.2/44573

DOI: $\quad$ DOI:https://doi.org/10.14195/978-989-26-16-506_56

Accessed : $\quad$ 26-Apr-2023 11:43:14

A navegação consulta e descarregamento dos títulos inseridos nas Bibliotecas Digitais UC Digitalis, UC Pombalina e UC Impactum, pressupõem a aceitação plena e sem reservas dos Termos e Condições de Uso destas Bibliotecas Digitais, disponíveis em https://digitalis.uc.pt/pt-pt/termos.

Conforme exposto nos referidos Termos e Condições de Uso, o descarregamento de títulos de acesso restrito requer uma licença válida de autorização devendo o utilizador aceder ao(s) documento(s) a partir de um endereço de IP da instituição detentora da supramencionada licença.

Ao utilizador é apenas permitido o descarregamento para uso pessoal, pelo que o emprego do(s) título(s) descarregado(s) para outro fim, designadamente comercial, carece de autorização do respetivo autor ou editor da obra.

Na medida em que todas as obras da UC Digitalis se encontram protegidas pelo Código do Direito de Autor e Direitos Conexos e demais legislação aplicável, toda a cópia, parcial ou total, deste documento, nos casos em que é legalmente admitida, deverá conter ou fazer-se acompanhar por este aviso.

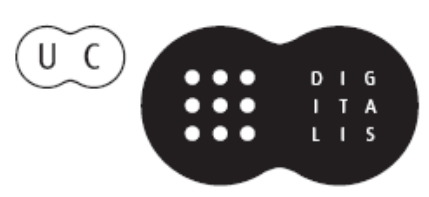




\section{ADVANCES IN}

\section{FOREST FIRE RESEARCH}

\section{8}

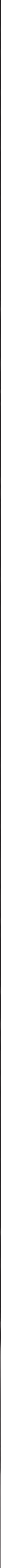




\title{
Improvement of Forest Fire Danger Rating in Russia
}

\author{
Alexandra V. Volokitina ${ }^{1}$; Tatiana M. Sofronova*2; Mikhail A. Korets ${ }^{3}$ \\ ${ }^{1}$ Sukachev Institute of Forest SB RAS, ul. Akademgorodok, 50/28, Krasnoyarsk 660036, Russia, \\ \{volokit@ksc.krasn.ru\} \\ ${ }^{2}$ Astafiev Krasnoyarsk State Pedagogical University, ul. A. Lebedevoy,89, Krasnoyarsk 660049, \\ Russia, \{tmsofronova@gmail.com*\} \\ ${ }^{3}$ Sukachev Institute of Forest SB RAS, ul.Akademgorodok,50/28, Krasnoyarsk 660036, Russia, \\ \{mik@ksc.krasn.ru\}
}

\begin{abstract}
The paper analyses three kinds of forest fire danger rating (FDR) in the Russian forest fire protection: 1) FDR according to weather conditions (fire weather danger rating); 2) FDR according to local (regional) scales (a combination of fire weather and fire hazard adjusted to local conditions), and 3) FDR according to vegetation fuel complexes (the so called fire hazard). Unfortunately, all the enumerated FDRs are realized via techniques of 1940s - 1970s in spite of the fact that there are improved techniques developed in the country. The constant personnel perturbations in the Federal Forestry Service of Russia and absence of qualified forestry experts there make it impossible to keep an eye and timely consider the methodical recommendations (practical guidelines) received from scientists and aimed at improvement of forest fire protection in Russia. The main focus is on methods of earth remote sensing and increase of technical power though the world experience shows that this is a dead-end way in resolving the vegetation fire issues.

Analysis of the available elaborations has shown that the most forward-looking are the recommendations realized on the basis of a long-term fundamental research in the leading forest fire science laboratory of Russia at the Sukachev Institute of Forest SB RAS. For the FDR according to weather conditions it is suggested that an index should be used which takes into account not only air temperature and dew point but also humidity and hygroscopicity of vegetation fuels and "works" even under negative air temperatures. Making local (regional) FDR scales is based on prediction of probable density of active fires per each day. And the basis of the FDR according to vegetation fuels (fire hazard rating) consists of the developed classification of vegetation fuels (VF) and methods of their mapping.

The results of our fundamental fire science studies suggest improvement of forest fire danger rating in protected areas and in areas with valuable indigenous coniferous stands of Siberian pine, fir, pine, larch, and spruce. Recommendations are given for more accurate assessment of a fire weather index and fire hazard, and for making improved comparable local (regional) fire danger scales. The recommendations are aimed at fire science specialists, fire protection specialists in protected areas, forest offices, and air patrol, emergency services employees, faculty and university students.
\end{abstract}

Keywords: forest fire danger, fire danger rating according to weather conditions, local (regional) scales of fire danger rating, method of assessing fire hazard

\section{Introduction}

Forest fire danger is impacted by a large number of factors, direct and indirect, which differ by their role and dynamics. The major factors are those which are indispensible for ignition to start. Firstly, there are vegetation fuels (VF) as complexes, with the available fuel load being most important characteristic. Secondly, there are weather conditions (relative air moisture and air temperature, drought level, precipitation) which predetermine occurrence and dynamics of the available VF load. Thirdly, there are ignition sources (probability of their occurrence).

In Russia, forest fire protection fulfills the following major tasks: fire detection and daily regulation of forest fire protection services; planning and conducting fire preventive activities; direct fighting of 
occurring and active fires and their management. According to the forest fire protection tasks the following three kinds of fire danger are distinguished in practice:

1) fire danger according to weather conditions expressed as an index, e.g., the Nesterov and PV1 Indices (Nesterov, 1949; Vonsky et al., 1975, 1976);

2) fire danger according to VF complexes (the so called fire hazard) defined by special scales that determine the degree of ease of ignition there (Melekhov, 1947; Ovsyannikov, 1978);

3) fire danger rating according to local (regional) scales which is a combination of fire weather and fire hazard adjusted to local conditions (Kurbatsky, 1954, 1963; Zhdanko, 1965).

All the enumerated kinds of forest fire danger require improvement. Possible ways of their improvement are considered in this paper.

\section{Improvement of Forest Fire Danger Rating According to Weather Conditions}

Russian fire danger rating according to weather conditions was realized via the comprehensive Nesterov Index starting from 1949 and since 1967 - via the meteorological Nesterov Index with rough account of precipitation where the precipitation sum of less than $3 \mathrm{~mm}$ is ignored and the precipitation sum equal to $3 \mathrm{~mm}$ and over resets the index to zero and the calculation starts over again (Kats et al., 1975). Since 1976 one more index, the PV-1 Index, was introduced with amore differentiated account of precipitation (Vonsky, Zhdanko, 1976).

As for foreign fire danger rating systems, their detailed analysis and conclusion about inexpediency of application in Russia were made by T.M. Sofronova with coathors (Sofronova et al., 2007). Performance tests showed no advantages among the tested foreign methods of fire danger rating according to weather conditions (Viegas et al., 1999).

Analysis of the available elaborations (not yet implemented in practice) has shown that the most forward-looking is the index developed by the leading forest fire science laboratory of Russia at the Sukachev Institute of Forest SB RAS. This index as a further development of the Nesterov and PV-1 indices takes into account not only air temperature and dew point but also humidity and hygroscopicity of vegetation fuels and "works" even under negative air temperatures that is very important for such Russian regions as Zabaikalie and the Far East where spring and autumn fires can occur and spread under negative air temperatures.

The base of Nesterov Index and PV-1 Index reflect conditions of gradual total evaporation from the free water surface. However, evaporation from hygroscopic bodies (moss, lichen, litter et al.) is partial till the level of equilibrium moisture content depending upon air temperature and relative air humidity. This is the reason why fruticose lichens and moss Schreberi (Pleurozium Schreberi Mitt.) do not dry up to burnable state under relative air humidity higher than $85 \%$ and $60 \%$, respectively. Without rain, long increase of relative air humidity can moisten mosses, lichens and litter into a burnable state while the fire weather index is growing. To overcome this disparity, the index base is suggested to be compensated by the hygroscopicity of fuels, namely: $-5^{\circ} \mathrm{C}$ iss added to the difference $\left(t-t_{d}\right)$. Therefore, when the difference $\left(t-t_{d}\right)$ is less than $5^{\circ}$, i.e. under the relative air humidity less than $85 \%$ in the afternoon, the index base becomes negative and the index itself decreases even without rain. For the new base to remain within the same level as the previous one, $+10^{\circ} \mathrm{C}$ is added to the first multiplier. This makes it possible to use almost the same scales. The new base acquires the following formula: $(t$ $\left.+10^{\circ}\right)\left(\mathrm{t}-\mathrm{t}_{\mathrm{d}}-5^{\circ}\right)$. The formulae for Nesterov (PN), PV-1 and PVG Indices are as follows:

$$
\mathrm{PN}_{\mathrm{n}}=\mathrm{PN}_{\mathrm{n}-1} \mathrm{~K}_{\mathrm{r}}+\left[\mathrm{t}\left(\mathrm{t}-\mathrm{t}_{\mathrm{d}}\right)\right]_{\mathrm{n}}
$$

$(\mathrm{PV}-1)_{\mathrm{n}}=\left\{(\mathrm{PV}-1)_{\mathrm{n}-1}+\left[\mathrm{t}\left(\mathrm{t}-\mathrm{t}_{\mathrm{d}}\right)\right]_{\mathrm{n}-1}\right\} \mathrm{K}_{\mathrm{r}}$;

$\left.(\mathrm{PVG})_{\mathrm{n}}=\left[(\mathrm{PVG})_{\mathrm{n}-1}+\left(\mathrm{t}+10^{\circ}\right)_{\mathrm{n}}\left(\mathrm{t}-\mathrm{t}_{\mathrm{d}^{-}} 5^{\circ}\right)\right]_{\mathrm{n}}\right]\left(\mathrm{K}_{\mathrm{r}}\right)_{\mathrm{n}}$, 
where $\mathrm{t}$ - air temperature at $2-3 \mathrm{pm},{ }^{\circ} \mathrm{C} ; \mathrm{t}_{\mathrm{d}}$ - dew point temperature at $2-3 \mathrm{pm},{ }^{\circ} \mathrm{C} ;{ }_{\mathrm{n}}$ - day for which index is calculated; $n-1$ - previous day; $\mathrm{K}_{\mathrm{r}}$ - precipitation coefficient for the sum of precipitation during previous 24 hours.

Testing the bases of indices in terms of the strength of their relationship with equilibrium moisture of wood showed that the correlation ratio of an old base $t\left(t-t_{d}\right)$ is equal to 0.91 and a new one $\left(t+10^{\circ}\right)(t$ $\left.-t_{d}-5^{\circ}\right)$ is equal to 0.99 . Thus, the index with a new base (PVG) is a bit higher in spring and lower in summer if compared with the PV-1 Index. Additional advantage of the PVG Index is that it can be calculated even under negative air temperature (up to $-10^{\circ} \mathrm{C}$ ) that is very important for Zabaikalie and the Far East where spring and autumn fires can occur and spread under negative air temperatures.

Precipitation account isalso suggested to be improved. When calculating the Nesterov Index, the sum of precipitation less than $3 \mathrm{~mm}$ corresponds to the precipitation coefficient equal to 1 . If the precipitation sum is more than $3 \mathrm{~mm}$, the precipitation coefficient is equal to 0 . The PV-1 index has a more differentiated account of precipitation starting from $0.5 \mathrm{~mm}$, special tables being made to facilitate calculations.

Analysis of existing precipitation coefficients and distribution of precipitation under canopies of different stands (Volokitina, 1979) lead to an improved precipitation coefficient (Sofronov et al., 2005; Sofronova et al., 2007):

$\mathrm{K}_{\mathrm{r}}=1.8 / \mathrm{R}+1$,

where R-sum of precipitation for the last 24 hours; if $\mathrm{R}<0.6 \mathrm{~mm} \mathrm{~K}=1$.

Analysis of duration and sum of precipitation on the Obninsk rainfall-measuring ground (Dmitriyev, Isayev, 1970) showed that $1 \mathrm{~mm}$ of precipitation falls approximately within 1.3 hours (i.e. $0.8 \mathrm{~mm}$ of precipitation per hour). Therefore, there is another option for the precipitation coefficient:

$\mathrm{K}_{\mathrm{r}}=1.8 /(1.3 \mathrm{~T}+1)$,

Where $\mathrm{T}$ - precipitation duration within 24 hours, $\mathrm{h}$; if $\mathrm{T}<0.5 \mathrm{~h}, \mathrm{~K}_{\mathrm{r}}=1$.

There is a table of precipitation coefficients for calculation of the PVG Index (Table 1).

Table 1 - Precipitation coefficients $\left(K_{r}\right)$ for actual precipitation $(\boldsymbol{R}, \mathrm{mm})$ (Sofronov et al., 1992)

\begin{tabular}{|c|c|c|c|c|c|}
\hline $\mathrm{R}, \mathrm{mm}$ & $0.6-1.5$ & $1.6-2.5$ & $2.6-3.5$ & $3.6-4.5$ & $4.6-5.5$ \\
\hline $\mathrm{K}_{\mathrm{r}}$ & 0.90 & 0.60 & 0.45 & 0.36 & 0.30 \\
\hline $\mathrm{R}, \mathrm{mm}$ & $5.6-6.5$ & $6.6-7.5$ & $7.6-8.5$ & $8.6-9.5$ & $9.6-10.5$ \\
\hline $\mathrm{K}_{\mathrm{oc}}$ & 0.26 & 0.22 & 0.20 & 0.18 & 0.16 \\
\hline $\mathrm{R}, \mathrm{mm}$ & $10.6-11.5$ & $11.6-12.5$ & $12.6-13.5$ & $13.6-14.5$ & $14.6-16.0$ \\
\hline $\mathrm{K}_{\mathrm{r}}$ & 0.15 & 0.14 & 0.13 & 0.12 & 0.11 \\
\hline $\mathrm{R}, \mathrm{mm}$ & $16.1-18.0$ & $18.1-20.0$ & $20.1-24.0$ & $24.1-28.0$ & $28.1-32.0$ \\
\hline $\mathrm{K}_{\mathrm{r}}$ & 0.10 & 0.09 & 0.08 & 0.07 & 0.06 \\
\hline $\mathrm{R}, \mathrm{mm}$ & $32.1-40.0$ & $40.1-50.0$ & $50.1-60.0$ & - & - \\
\hline $\mathrm{K}_{\mathrm{r}}$ & 0.05 & 0.04 & 0.03 & - & - \\
\hline
\end{tabular}

Thus, the proposed PVG Index has the following advantages: 1) takes into account hygroscopicity of vegetation fuels, namely primary fire carriers (moss, lichen, litter); 2) works under negative temperatures (up to $-10^{\circ} \mathrm{C}$ ) that is very important for regions with spring and autumn fires spreading under negative temperature in the areas with grass and cured grass type of primary fire carrier; 3) uses an improved precipitation coefficient; 4) is calculated twice as an index of the previous day and a predicted index of a coming day.

\section{Improvement of forest fire danger rating using local (regional) scales}


The link between weather and daily fire danger level is not straightforward because of the impact of other fire danger factors. At present this link is defined through a system of regional scales which formerly were called "local scales of fire danger according to weather conditions".

The currently used technique of making local (regional) scales of forest fire danger rating developed by N.P. Kurbatsky (1954) generates fire danger classes incomparable even in adjacent regions with different forest vegetation conditions. For instance, under the same fire danger class in different forest offices the number of active fires per unit of area can be different. This prevents effective maneuvering of the available (usually insufficient) forces and means of forest fire protection.

The improved method of making local (regional) fire danger rating scales implies prediction of probable density of active fires per each day. Examples of such scales are made for the Chunsky Forest Office (Krasnoyarsky krai) which is most prone to wildfires. An algorithm for automatized creation of regional scales has been developed together with a beta version of the software (Volokitina et al., 2018).

Ten-year fire and weather data (2005-2014) of the Chunsky Forest Office (Krasnoyarsk krai) was obtained from the Krasnoyarsk Forest Fire Center for development of a technique for making improved regional scales of fire danger rating. An earlier developed principle method of making regional scales was applied (Kurbatsky, 1963), i.e. the empirical dependence between the long-term data on fire weather indices and the daily number of fires during a fire season in a specific area (a forest office). Moreover, an absolute criterion, fire density (fires per million ha), was introduced for distinguishing comparable classes of fire danger in regional scales (Sofronov, 1985). However, unlike the previously offered density of occurring fires, we used density of active fires, since its number is approximately twice higher than that of occurring fires according to the comparative analysis of long-term fire data (30 years). Therefore the recommended earlier gradations of fire density for fire danger classes were increased by the factor of 2 . We assumed that fire density changes by the factor of 4 from class to class in order to cover the whole range of possible fire densities in the given area (forest office) (Table 2) (Sofronova et al., 2007).

Table 2 - Gradation of fire danger classes by fire density

\begin{tabular}{|l|l|l|}
\hline \multirow{2}{*}{ Fire danger classes } & \multicolumn{2}{|l|}{ Fire density for a given day, fires / million ha } \\
\cline { 2 - 3 } & ocurring fires & active fires \\
\hline I & up to 0.10 & up to 0.20 \\
\hline II & $0.10-0.4$ & $0.20-0.8$ \\
\hline III & $0.41-1.6$ & $0.81-3.2$ \\
\hline IV & $1.61-6.4$ & $3.21-12.8$ \\
\hline V & over 6.4 & over 12.8 \\
\hline
\end{tabular}

It is very important to know the distribution of fires within a fire season (from April till September in the area of our study) for arrangement of forest fire protection. The considered 10-year period showed a sharp increase in number and area of fires starting from the second 10-day period in May and reaching its peak in the third 10-day period in June.

To elaborate optimal regional scales for the Chunsky Forest Office, we analyzed a mean daily number of active forest fires in relation with drought classes and their dynamics within a fire season for 10-year period (2005-2014) (Fig. 1). 


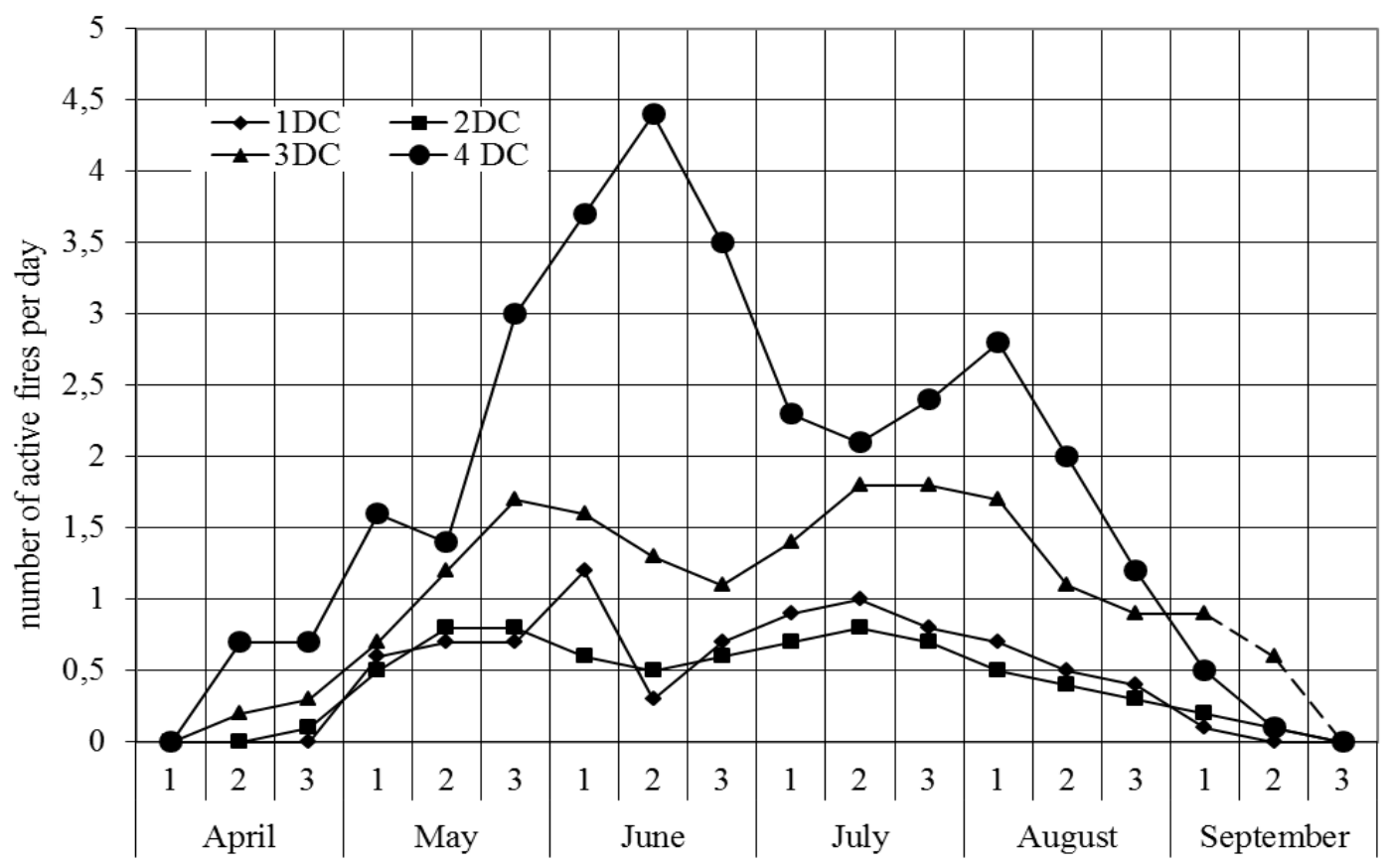

Figure 1 - Mean daily number of active forest fires in relation with drought classes (DC) and their dynamics within a fire season (based on 2005-2014 data, Chunsky Forest Office). DCs correspond to the following gradation of the PV-1 and PVG Indices: 1 DC - up to 300, 2 DC-301-1000, 3 DC-1001-3000, 4 DC-3001-10000, etc.).

Taking into account the dynamics of active fires which differs within a fire season, regional scales were made seperately for two periods of a fire season (from April 20 till June 30 and from July 1 till September 20) (Tables 3 and 4). Since the density of active fires for the period from 2005 till 2014 did not exceed the fourth fire danger class, the fifth class was not defined. However, the fifth class for this area can be theoretically assessed in case of extreme droughts.

Table 3 - Regional scales for the Chunsky Forest Office for the period from April 20 till June 30 (based on data from 2005 till 2014)

\begin{tabular}{|c|c|c|}
\hline Fire danger class & PV-1 Index value & Fire density per million ha \\
\hline I & up to 100 & up to 0.2 \\
\hline II & $101-800$ & $0.2-0.8$ \\
\hline III & $801-5200$ & $0.81-3.2$ \\
\hline IV & over 5200 & $3.21-12.8$ \\
\hline V & - & over 12.8 \\
\hline
\end{tabular}

Table 4 - Regional scales for the Chunsky Forest Office for the period from July 1 till September 20 (based on data from 2005 till 2014)

\begin{tabular}{|c|c|c|}
\hline Fire danger class & PV-1 Index value & Fire density per million ha \\
\hline I & up to 400 & up to 0.2 \\
\hline II & $401-1600$ & $0.20-0.8$ \\
\hline III & $1601-6000$ & $0.81-3.2$ \\
\hline IV & over 6000 & $3.21-12.8$ \\
\hline V & - & over 12.8 \\
\hline
\end{tabular}


Making regional fire danger scales manually takes considerable time. Having all the necessary information it is possible to automatize this process (Sofronova et al., 2013).

The following input data are needed to develop an programme algorithm: 1) area, million ha; 2) value of PV-1 or PVG Index per each day of a fire season for the last 10 years; 3 ) number of active fires per each day of a fire season for the last 10 years; 4) periods of a fire season.

The programme algorithm includes the following operations:

1. Group fire data within gradually expanding gradation of fire weather index values.

2. Calculate mean number of daily active fires within each gradation and assess density of daily active fires per million ha.

3. Make a correlation graph (crossing zero) between mean daily fire density and gradation of a fire weather index and define gradations of a fire weather index according to the scale with comparable fire danger classes: I FDC - up to 0.2; II FDC - 0.2-0.8; III FDC - 0.81-3.2; IV FDC - 3.2-12.8; V FDC - over 12.8 fires per million ha.

4. Make a regional scale as a table or a diagram.

The proposed improved regional scales of fire danger rating in the forest can help to assess more accurately a propbable daily density of active fires under each fire danger class. This will facilitate timely detection of occurring fires and more efficient manipulating of suppression forces and resources not only among forest offices (air patrol departments, regions) but also within one forest office (region) during different periods of a fire season as the tension of a fire situation in each area and in each period of a fire season will become comparable.

To help automatize regional assessment of daily fire danger we developed a program for making improved regional fire danger scales and made a beta version of the software (Sofronova et al., 2013).

\section{Improvement of fire danger rating according to vegetation fuel complexes (fire hazard)}

According to N.P. Kurbatsky (1972), the fire danger according to vegetation fuel (VF) complexes is a fire danger which is predetermined by the features of the area and related to a long-term period (under the assumption of constant availability of ignition sources which may cause a wildfire).

Russia still uses the scale for assessing forest plots by the degree of fire occurrence danger (Melekhov, 1947; Ovsyannikov, 1978) when planning fire prevention of the forest office territories. This scale only roughly assesses the integrated fire hazard.

The improved fire hazard rating is suggested to be based on the VF maps which contain information about all VF complexes of a given area and their characteristics. The main characteristic is the rate with which primary fire carriers become ready to burn. Methods of making VF maps have been developed. On their basis it is possible to make more accurate maps of fire hazard as well as maps of current fire hazard depending upon the class of drought. The information database for making such maps in GIS is developed for the Chunsky Forest Office (Krasnoyarsky krai) with area of 1 million ha. Besides fire hazard rating, the VF maps make it possible to predict behavior of an occurred fire, i.e. its spread rate, possible development (i.e. from the surface fire into the crown or ground fire), and its effects.

\section{Conclusion}

As a result of the carried out research the background was analyzed on forest fire danger according to weather conditions, according to VF complexes and according to regional scales. 
It is suggested that improvement of forest fire danger rating should be based on the results of fundamental research of the rate with which primary fire carriers become ready to burn in relation to the weather conditions and on the developed VF classification and methods of VF mapping.

Each kind of fire danger rating currently used in Russia is provided with recommendation on improvement of its performance (e.g., more accurate fire weather index calculation, improved comparable regional fire danger scales, etc.).

The proposed improvement will modernize fire danger rating according to weather conditions and regional scales as well as according to VF complexes.

\section{Acknowledgements}

The study was done within the framework of the basic project at the Sukachev Institute of Forest SB RAS \# VI.52.2.2 under partial support of the Russian Foundation For Basic Research grant \# 1805-00781A.

\section{References}

Dmitriyev AA, Isayev AA (1970) Evaluation of the possibility for extending the results of observation on the reference station over total daily precipitation to the surrounding area. Meteorologiya $i$ gidrologiya 9, 46-53.

Kats AL, Gusev VA, Shabunina TA (1975) 'Methodical guidelines for forest fire danger prediction according to weather conditions.' (Gidrometeoizdat: Moscow)

Kurbatsky NP (1954) Methodical guidelines for experimental development of local scales of fire danger.' (TsNIILH: Leningrad)

Kurbatsky NP (1963) Forest fire danger and its assessment by local scales. In 'Forest fires and their fighting'. pp. 5-30. (AN SSSR: Moscow)

Kurbatsky NP (1972) Terminology of forest fire science. In 'Issues of forest fire science'. pp. 171231. (ILiD: Krasnoyarsk)

Melekhov IS (1947) 'Nature offorest and forest fires.' (OGIZ: Archangelsk)

Nesterov VG (1949) 'Forest fire occurrence and methods of its assessment.' (Goslesbumizdat: Moscow)

Ovsyannikov IV (1978) 'Fire prevention arrangement of forests.' (Lesnaya promyshlennost: Moscow)

Sofronov MA (1985) 'Methodical guidelines for using standard regional scales of forest fire danger.' (ILiD SO RAN SSSR: Krasnoyarsk)

Sofronov MA, Volokitina AV, Fomina OA, Tartakovskaya TM (1992) 'Methodical guidelines for current fire danger assessment and prediction based on maps of forest fuels and weather forecasts.' (ILiD: Krasnoyarsk)

Sofronov MA, Volokitina AV, Korets MA, Sofronova TM, Mikhaylova IA (2005) 'Fire danger in natural conditions.' (IL SO RAN: Krasnoyarsk)

Sofronova TM, Volokitina AV, Pershin KS (2013) Automatized creation ofimproved local scales of fire danger. Vestnik KrasGAU 3, 157-163.

Sofronova TM, Volokitina AV, Sofronov MA (2007) 'Improvement of fire danger rating according to weather conditions in mountain forests of the South Baikal Lake basin.' (IL SO RAN, KUPU: Krasnoyarsk)

Viegas X, Bovio G, Ferreira A, Nosenzo A, Sol B (1999) Comparative study of various methods of fire danger evaluation in southern Europe. International Journal of Wildland Fire 9, 235-246. 
Volokitina AV (1979) Specifics of rain precipitation distribution under forest canopy. Lesovedenie 2, 40-48.

Volokitina AV, Sofronova TM, Korets MA (2018) 'Improvement of forest fire danger rating.' (IL SO RAN, KGPU: Krasnoyarsk)

Vonskiy SM, Zhdanko VA (1976) 'Principles for development of forest fire weather indices.' (LenNIILH: Leningrad)

Vonsky SM, Zhdanko VA, Korbut VI, et al. (1975) 'Assessment of forest fire hazard.' (LenNIILH: Leningrad)

Zhdanko VA (1965) 'Scientific fundamentals of making regional scales and their importance in fire prevention.' (Lesnaya promyshlennost: Moscow) 